\title{
FENOMENOLOGÍA CLÍNICA \\ DE LOS SIETE PECADOS CAPITALES
}

\section{CLINICAL PHENOMENOLOGY OF SEVEN DEADLY SINS}

\author{
Manuel Villegas Besora \\ Universidad de Barcelona, Facultat de Psicologia. España \\ ORCID: https://orcid.org/0000-0002-5584-8469
}

Cómo referenciar este artículo/How to reference this article:

Villegas Besora, M. (2020). Fenomenología clínica de los siete pecados capitales. Revista de Psicoterapia, 31(116), 147-168. https://doi.org/10.33898/rdp.v31i116.412

\section{Resumen}

El tema de los pecados capitales ha estado presente bajo diversas formas, tanto en el pensamiento filosófico como en el religioso oriental y occidental, estoicismo, budismo o cristianismo entre ellas. Aquí se consideran desde una perspectiva psicológica contemporánea en su fenomenología clínica más habitual.

Palabras clave:fenomenología, psicología clínica, culpa, pecado, relaciones interpersonales.

\begin{abstract}
The theme of deadly sins has been present in various forms, both in philosophical thought or in eastern and western religious traditions: Stoicism, Buddhism or Christianity among them. Here they are considered from a contemporary psychological perspective in their most common clinical expressions.
\end{abstract}

Keywords: phenomenology, clinical psychology, guilt, deadly sins, interpersonal relationships. 


\section{Introducción}

El concepto tradicional de "pecados capitales" se refiere a aquellas actitudes en relación a nosotros mismos, al mundo y a los demás, que son el origen de las motivaciones egocéntricas responsables de muchos de los problemas interpersonales, internos e incluso ecológicos que nos afectan a lo largo de la vida, independientemente de la época histórica o el marco socio-cultural en que nos movemos. En este sentido tienen un carácter atemporal que ha sido recogido bajo diversos nombres por la literatura, la filosofía, las religiones, los mitos, el cine o el teatro, y que dan lugar a muchas de las manifestaciones de la fenomenología clínica que vemos en psicoterapia. Las relaciones de dominio sumisión o dependencia, el maltrato físico y psicológico, el narcisismo, la compulsiones consumistas, las actitudes destructivas, la violencia interpersonal, la procrastinación, la infidelidad, etc., tienen que ver sin duda con la lista completa de los 7 pecados capitales, como la soberbia, la ira, la lujuria, la gula, la envidia, la avaricia o la pereza.

\section{Pecado y culpa}

Los psicólogos estamos habituados a manejarnos con el sentimiento de culpa, que frecuentemente expresan nuestros pacientes, de las formas más variadas: temor al castigo, vergüenza pública o privada, contrición por el mal causado o remordimiento por el bien que hemos dejado de hacer y podríamos haber hecho.

La palabra culpa (de idéntico origen latino) hace referencia a la causa (culpa) de un daño o perjuicio (pecado), de modo que se puede aplicar incluso a fenómenos no intencionados (por culpa de la lluvia).

La palabra pecado de «peccatum» (en latín tropiezo) significa falta o acción culpable. En la concepción religiosa eso implica desobediencia a Dios y sus leyes. En la ley mosaica hay tres mandamientos teocéntricos, que se refieren al respeto y culto de Dios, y siete antropocéntricos, que toman en cuenta el respeto y cuidado de los demás (no matar, no robar, no mentir, no levantar falso testimonio). En la concepción laica hace referencia a la comisión del mal del que uno es responsable moralmente, legalmente, económicamente. En estos casos solemos hablar de delitos por los cuales alguien es inculpado.

Pero ¿cómo podemos tratar con el sentimiento de culpa si no reconocemos el concepto de pecado? ¿De qué sentimos culpa? Reconocer el sentimiento de culpa implica reconocer el concepto de pecado. Sin embargo, no existe una relación biunívoca entre ellos. Sentir culpa no implica necesariamente haber cometido un pecado. Ni haber cometido un pecado implica necesariamente sentir culpa.

\section{Tipologías de pecado}

Puede sentirse culpa por pecados de comisión u omisión.

a) Pecados de comisión

Los pecados de comisión implican un daño infligido realmente en cualquier ámbito: natural (ecología), social (guerra), interpersonal (calumnia), propio (autole- 
siones). Así se entiende que una paciente bulímica se pueda sentir culpable después de un atracón. O un alcohólico, de estar arruinándose la vida. En los pecados de comisión la palabra mal tiene un carácter sustantivo: "el mal”.

b) Pecados de omisión

Los pecados de omisión hacen referencia al daño derivado de la dejación en prestar una atención o cuidado, estando obligados a hacerlo (negligencia). Por ejemplo, no haber prestado atención o protección a una víctima de abusos en el ámbito familiar, o de accidente en una carretera. Se entiende en este contexto que muchas madres puedan sentirse culpables de no haber cuidado suficientemente de sus hijos a causa de sus ocupaciones profesionales o de no haberlos educado apropiadamente. No siempre está clara la distinción entre pecado de omisión y fallo.

c) Fallos o errores

También podemos sentir culpa o, más frecuentemente vergüenza, por los fallos o errores, por algo que hemos hecho mal o no hemos sabido hacer (mal como adverbio, mal formal: error, defecto). Por ejemplo, un error de diagnóstico médico, más allá de sus consecuencias perjudiciales, puede ser motivo de vergüenza. Además, si las consecuencias son perjudiciales para el paciente puede sentirse culpa moral o incluso ser inculpado legalmente. La responsabilidad en estos casos es directa.

Otras veces se trata de imperfección en el resultado, por ejemplo un defecto de fabricación o por defecto de mantenimiento. La existencia de daños subsiguientes puede ser atribuible o no al fallo o error. La responsabilidad en eso casos puede ser directa o indirecta.

\section{Falsa culpabilidad}

Se refiere a un sentimiento inadecuado de culpabilidad por algo que no se ha hecho, ni dejado de hacer. Se puede sentir culpable, por ejemplo, de un mal que hemos compartido, como víctimas, pero no causado como agentes (culpa del superviviente). A este tipo de sentimiento de culpa lo consideramos falsa culpabilidad, precisamente porque el sujeto no ha sido causa, sino víctima del daño compartido. Un tipo de sentimiento parecido deriva de una atribución futurible de culpa en ausencia de responsabilidad real: «si le pasara algo a mi hijo...». Se trata de una culpa anticipatoria u obsesiva dirigida a evitar algo que todavía no ha sucedido y que tal vez no vaya a suceder. A veces se presenta con efectos retroactivos, en el caso de que llegue a suceder: "si me hubiera opuesto con más fuerza a que mi hijo saliera de fiesta aquella noche...", pero con el mismo carácter preventivo, que lo reconduce a sentimiento de falsa culpabilidad.

\section{Concepción moral vs. legal}

El tema del pecado, como el de la culpa, se puede enfocar desde la perspectiva moral o la legal.

\section{a) Concepción moral}

El concepto de pecado corresponde a una concepción moral, independien- 
temente de su origen religioso o no. Puede entenderse como daño causado a los demás a partir de motivaciones egocéntricas dominantes por acción u omisión. Su carácter pecaminoso radica precisamente en esta motivación egocéntrica, causante de males ajenos. Ni el error, ni la falsa culpabilidad pueden considerarse moralmente pecado, puesto que se supone que no existía motivación dañina en el error, ni participación activa en la falsa culpabilidad.

\section{b) Concepción legal}

En el ámbito legal no se habla de pecado sino de delito. Por tal se entiende cualquier acción contraria a la ley penal (crimen) (asalto a mano armada en una joyería, estafa, violación...). Otro concepto afín es el de infracción: incumplimiento o inobservancia de una normativa (aparcamiento en zona prohibida, saltarse un semáforo en rojo...). Delitos e infracciones están sujetos a penalizaciones de tipo personal o económico. Se prescinde de su carácter moral o inmoral.

\section{Efectos psicológicos diferenciados para pecado y delito}

Pedro de 17 años es contactado por Laura de 12 a través de Instagram para un encuentro sexual con penetración. Acusado por los padres de la chica ante el Tribunal de Menores, manifiesta que no sabía la edad de la menor, ni que esto a nivel legal tuviese implicación alguna. Manifiesta, igualmente, tener una necesidad sexual muy grande; que no le importa si la chica es más o menos guapa. Lo único que le importa es satisfacerse.

El caso presenta en su simplicidad un claro efecto de concebir una acción desde una perspectiva moral (pecado) o legal (delito), aunque ambas puedan sobreponerse en la práctica. En la gráfica siguiente pueden verse a dos columnas las familias conceptuales implicadas bajo un epígrafe u otro, concepción moral o legal, en relación a su peso en la regulación psicológica. En concreto, y aplicado al caso de Pedro y Laura, podemos hacer las siguientes observaciones.

$\begin{array}{lll}\text { - } \text { Concepción moral } & \leftrightarrow & \text { Concepción legal } \\ \text { - } \text { Concado } & \leftrightarrow & \text { Delito } \\ \text { - Responsabilidad } & \leftrightarrow & \text { Código penal } \\ \text { - Reconocimiento } & \leftrightarrow & \text { Imputabilidad } \\ \text { - Contrición } & \leftrightarrow & \text { Excusas, Justificación } \\ \text { - Culpa } & \leftrightarrow & \text { Vergüenza } \\ \text { - Reparación } & \leftrightarrow & \text { Castigo } \\ \text { - Perdón } & \leftrightarrow & \text { Indulto }\end{array}$

Pedro concibe los acontecimientos desde la perspectiva legal. La primera cosa que arguye en su defensa es que no sabía la edad de la menor. Ambos son menores de edad, aunque les separan cinco años de diferencia. Su defensa esgrime el argumento no solo del consentimiento de la chica, sino de su iniciativa en el encuentro a través de Instagram. Sin embargo, en el momento de los hechos la edad del consentimiento para un intercambio sexual estaba en trece años (en la actualidad, desde 2016, ha 
subido a la edad de dieciséis años), Laura tenía solo doce.

Es decir, Pedro concibe los hechos únicamente desde la perspectiva legal. Intenta escurrir la imputabilidad legal, negando que su encuentro con Laura constituyera un delito según el código penal. Alega ignorancia de la ley y de la edad de la menor. Se excusa o justifica en base a su necesidad de satisfacerse sexualmente, como algo legítimo, independientemente de las características de la otra persona implicada.

Desde el punto de vista moral, en cambio, está claro que Pedro actúa de forma totalmente egocéntrica, precisamente porque no considera las condiciones de vulnerabilidad de Laura. No muestra conciencia de pecado, ni de responsabilidad en su comportamiento (debería haberse preocupado de conocer la condición de menor de la chica). No hay signos de culpa ni de contrición, solo vergüenza por verse llevado ante los tribunales y atrición por miedo al castigo.

\section{El concepto de pecado capital}

El calificativo de "capital" referido a los siete pecados capitales, proviene del latín: (caput/capitis), que significa cabeza. Se consideran pues pecados "cabeza", origen de todos los demás.

En sí mismos no son pecados, no son acciones ni omisiones, sino estados afectivos, actitudes o motivaciones, maneras de estar en el mundo o de comportarse hacia los demás.

Deben su categorización al monje Evagrio Póntico (2013) en el siglo IV, quien inicialmente los clasificó en 8 categorías, hasta que el Papa Gregorio Magno, en el siglo VI, los redujo a los 7 actuales: soberbia, ira, envidia, codicia (avaricia), lujuria, gula, pereza.

En el budismo se hablan de los tres venenos: la codicia, la ira y la ignorancia.

En el estoicismo existe un concepto parecido al de pecados capitales, el de vicios opuestos a virtudes o defectos.

\section{Concepción psicológica de los pecados capitales}

El egocentrismo moral está en la base de los pecados capitales. Es el caldo de cultivo en el que germinan todos ellos. Su único criterio de acción son: las propias necesidades (prenomía) o deseos (anomía), sin tener en cuenta el bien común (heteronomía), ni a los demás (socionomía).

Su carácter puede ser de naturaleza social, efecto de la contraposición entre los propios intereses y los sociales, donde inevitablemente entre en juego la relación con el otro: soberbia, envidia, ira. Su activación deriva de la erótica del poder.

O bien de naturaleza hedonista, centrados en la propia satisfacción, con independencia de los efectos sobre los demás: lujuria, gula, pereza. Su activación deriva de la erótica del placer.

Finalmente de naturaleza mixta: codicia, derivada de la combinación entre la erótica del poder y la del placer.

Naturalmente estas tendencias pueden combinarse, sumarse o potenciarse 
entre sí. Como decía Mateo Alemán (s. XVI): “La soberbia ataca con dos dardos: la ira y la envidia”. Pero vamos a considerarlos ahora individualmente por separado:

\section{Soberbia}

Soberbia de super, una preposición latina que significa sobre, estar por encima (super-bia). Se trata de un concepto interpersonal o relacional. Nadie puede estar por encima si no hay alguien por debajo de forma real o imaginaria.

María Moliner (2007) la define en su diccionario como: "Cualidad o actitud de la persona que se tiene por superior a las que la rodean por su riqueza, por su posición o por otra cualidad y circunstancia y que desprecia y humilla a los que considera inferiores". Definición que de modo más sintético recoge la RAE (2019): "Satisfacción y envanecimiento por la contemplación de las propias prendas con menosprecio de los demás”.

Dos son, pues, los componentes básicos de la soberbia:

- la creencia en la propia superioridad.

- la humillación o desprecio de los demás.

\section{La clínica de la soberbia: el narcisismo}

En síntesis, podemos definir la soberbia como un "sentimiento de superioridad frente a los demás que provoca un trato distante o despectivo hacia ellos". Todo ello suena a una manifestación derivada del narcisismo que la psicología cataloga de trastorno de la personalidad. El término narcisismo remite al relato mitológico, recogido por Ovidio en las "Metamorfosis", titulado Eco y Narciso.

Para Narciso los otros no son sujetos, sino objetos, y eso le impide relacionarse con ellos de forma profunda, íntima, amorosa, de tener sentimientos hacia los demás, incapaz de sentir empatía. Narciso se consume en este enamoramiento inalcanzable de sí mismo. A los demás los necesita como espejo, como eco, pero cuando encuentra a Eco en persona es incapaz de quererla. A los otros los trata como objetos que en sí mismos carecen de entidad. Narciso es imagen y Eco es voz, pero ninguno de los dos tiene entidad, porque uno se pierde en la imagen y el otro se pierde en la voz, ambas son efímeras, la voz suena y desaparece, la imagen se diluye cuanto más te acercas a ella. El mito contiene casi todos los elementos del narcisismo, desde la perspectiva clínica:

- Desdoblamiento del yo (sujeto) y los demás (objeto)

- Enamoramiento de sí mismo

- Necesidad de reconocimiento

- Engreimiento (soberbia)

- Incapacidad de amar

- Falta de empatía

- Reacción depresiva ante la frustración

Sin embargo, si prescindimos de un planteamiento clínico y nos atenemos a una característica de personalidad, seguramente podemos ponernos fácilmente de 
acuerdo en que el narcisismo o los rasgos narcisistas son claramente observables en las personas orgullosas.

En otras ocasiones hemos (Villegas y Mallor, 2012, 2015, 2018) desarrollado detalladamente las diversas modalidades narcisísticas, aristocrática, meritocrática y plutocrática, correspondientes a los diversos momentos evolutivos del proceso de desarrollo moral, según una dimensión progresiva entre lo innato y lo adquirido, que pasamos a considerar a continuación.

\section{La modalidad aristocrática}

En esta progresión la primera modalidad sería la aristocrática (el gobierno de los nobles). El narcisismo aristocrático parte del supuesto que el propio valor proviene de la cuna. En su blasón nobiliario se podría grabar el siguiente lema: "Valgo por hidalgo", es decir: "hijo de algo". Se considera innato o congénitamente heredado, cuyo reconocimiento es socialmente debido, sin necesidad de otros méritos. Llevan muy mal que alguien se atreva a cuestionar su valía congénita, por lo que pueden usar la seducción, intentando atraer la admiración de otras personas a base de acercarse a ellas ofreciendo la cara más amable y lisonjera de que son capaces. En caso de no obtener el reconocimiento esperado de los demás, pueden adoptar una forma de despotismo con el ejercicio de la fuerza o la violencia, si lo consideran necesario, a fin de obtener su sometimiento. A falta de éxito con las estrategias anteriores, pueden echar mano de la despectiva: el desprecio, como forma de situarse en una posición superior al colocar sistemáticamente a los demás en una posición inferior. Y, en último término, si no pueden en la práctica someter o interiorizar a los demás, pueden intentar mantener su mundo glorioso en el ámbito de la fantasía, a través de la modalidad elusiva; encerrados en su torre de marfil se sienten reconocidos por un público imaginario que les aplaude de modo incondicional.

\section{La modalidad meritocrática}

La segunda correspondería a la meritocrática, el gobierno de los excelentes. Los narcisistas meritocráticos creen que han conseguido suficientes logros, en el campo que sea, como para merecer un reconocimiento público. A diferencia, en cambio, de los aristocráticos, deben estar continuamente demostrando que son capaces de sostenerse en el nivel alcanzado. De ahí el perfeccionismo como recurso virtuosista de excelencia.

Michelangelo Buonarroti, por ejemplo, llegó a ser un gran escultor, pintor y arquitecto, a pesar de los prejuicios y la oposición de su padre, que, siendo de familia noble, no podía aceptar que su hijo quisiera ser escultor, "un trabajo de artesanos”. La tenacidad de Michelangelo consiguió, sin embargo, aunque a costa de desarrollar una personalidad con rasgos claramente obsesivos, alcanzar la cúspide del arte de todos los tiempos, además de ganar suficiente dinero como para reparar la ruina económica de su familia de origen. Todo su empeño parecía dirigido a conseguir por sus méritos lo que la nobleza le negaba, al desertar de una 
familia aristocrática arruinada.

\section{La modalidad plutocrática}

La tercera correspondería a la plutocrática. La plutocracia, de plutos (en griego), gobierno de los ricos, busca compensar los déficits personales con la adquisición de bienes apreciados socialmente. A falta de nobleza de estirpe o de méritos contraídos, una tercera alternativa para conseguir la exaltación frente al resto del mundo es la distinción que procura la acumulación de los bienes materiales o sociales, que pueden dar lugar a la fama en círculos más próximos o lejanos o, incluso, virtuales. Existen dos modalidades básicas de ostentación que pueden andar conjuntamente o por separado y que hemos denominado material y social.

\section{La modalidad plutocrática material}

Los bienes materiales no solamente pueden dar seguridad sino también prestigio social y sirven para ensalzar a su poseedor. No siempre la riqueza ha acompañado a la nobleza, con frecuencia arruinada, sino que ha dado lugar a la aparición de una nueva casta, "los nuevos ricos", los cuales carecen de abolengo pero lo compensan con la posesión o adquisición de bienes que les permiten competir con los mejor situados socialmente. Aristóteles Onassis pasó de limpiar cristales en su juventud a convertirse en la fortuna más grande de su época, armador y dueño de flotas petroleras, de compañías de aviación, del casino de Montecarlo, y otros innumerables negocios.

\section{La modalidad plutocrática social}

Otra forma de compensar el déficit de méritos personales es rodeándose de personas o contextos que mejoren el prestigio social como por contagio. "Quien a buen árbol se arrima, buena sombra la cobija”. Incluso los reyes más absolutos necesitan hacerse acompañar de una corte de nobles que exalten su realeza. Este tipo de personalidades se jactan de su círculo de amistades, de sus contactos con personas famosas o influyentes o de sus relaciones amorosas con personas de destacado atractivo que exhiben como un trofeo. Conocen a medio mundo y hacen ostentación de los contactos con profesionales de alto prestigio o políticos influyentes. Olvidan que "aunque la mona se vista de seda, mona se queda". El mismo Onassis mantuvo relaciones con la más alta sociedad y entre sus parejas tuvo a María Callas como amante y a la viuda de John F. Kennedy, Jacqueline, como última esposa.

\section{La soberbia en las relaciones íntimas}

Estas modalidades tienen especial incidencia en las relaciones interpersonales, particularmente en las de pareja. Margarita y Roberto son una pareja de treintañeros que acuden a terapia por sus continuas discusiones. Ella por sus orígenes familiares y la posición económica de sus padres, su historial académico, su profesión de azafata y su físico agraciado y esbelto pertenece a las categorías aristocrática y 
plutocrática del narcisismo. Él por sus orígenes humildes y su esfuerzo de superación en los estudios, el trabajo y la profesión pertenece a la categoría meritocrática del narcisismo.

Esas diferencias se trasladan a la dinámica de la relación con continuas discusiones sobre el fondo de "yo soy más que tú", hasta el punto que en sesión se hace evidente no solo en lo que dicen, sino en el posicionamiento postural, ella erguida y él replegado sobre sí mismo, excepto cuando reivindica sus méritos A propósito de esta observación por parte del terapeuta, Roberto interviene diciendo:

"Hay un fantasma en nuestra relación. El conflicto que tenemos es el tema, dicho en broma o en serio, pero que lo tiene muy interiorizado: "La guapa de la relación soy yo". Durante mucho tiempo era como el sentimiento de que "yo soy más que tú". A veces lo ha exteriorizado así, no solo por el tema físico, sino porque "he ido a un mejor colegio que tú", la posición económica de sus padres era mucho mejor que la de los míos en su momento... A mí me pasa eso: es la sensación de no ser suficiente.

Sin embargo -dirigiéndose a ella- estás viviendo en mi casa, yo tengo un trabajo, estoy haciendo muchas cosas, diciéndote valora lo que estoy haciendo, valórame a mí, que lo que tú hiciste en el pasado o lo que has sido o lo que eres da igual, pero estás conmigo, y te voy a dar lo mejor de mis posibilidades. Hay un poco de reivindicación por mi parte.

Esta situación genera cierta tensión. Ella ha pasado por muchas cosas: sus padres se han separado recientemente, el trabajo, los años de paro, etc. ha habido un conflicto muy grande y a mí a veces eso me genera un poco de falta de reconocimiento por su parte... Cuando acabé la carrera era el primero de mi clase, siempre he tenido muy buen reconocimiento por parte de todo el mundo; mis amigos, si quieren contar con alguien, van a contar conmigo, soy fiable, soy una persona educada y que no me vea así mi pareja me irrita enormemente...

Y ella me pasa por la cara que: "yo he ido al liceo francés y tú al colegio público, hablas mal porque vienes de tal barrio" y esto a mí me jode. Soy una persona bien reconocida en el trabajo, tengo mi piso, he conseguido muchas cosas, deberías estar orgullosa de mí, estar contenta de estar conmigo".

Aunque descritas por separado por razones de exposición, todas estas modalidades pueden combinarse parcial o totalmente entre sí, tal como viene a demostrar la frase de Cristiano Ronaldo: "Será porque soy guapo (aristocracia), rico (plutocracia) y un gran futbolista (meritocracia), porque me tienen envidia. No tengo otra explicación”.

\section{Ira}

La ira es una respuesta emocional de carácter agresivo a una frustración o daño, que implica una percepción de injusticia y conlleva un intento de restitución o reparación. 


\section{Romántico y matón}

José Luis describe una historia de descontrol de la ira y por este motivo acude a terapia. En el siguiente diálogo trata de definir su problema con el "control emocional" de la ira.

José Luis (P).: Yo tengo los dos extremos, el cariñoso, el sensible, el romántico. Soy muy romántico, aunque no lo parezca... Pero, por otra parte, tampoco tengo límites... Porque pierdo los estribos. Es que no sé controlarlos, y eso que ya tengo 40 años...

Terapeuta (T).: Cuando dices que no lo controlas ¿qué quieres decir?, ¿qué pasaría si te descontrolaras?

P.: Pues que podría llegar a matar por ejemplo. Seguro

T.: Pero, ¿a quién?

P.: A quien se me ponga en mi camino y trate de impedirme lo que yo considere justo o que haga daño a mi familia.

Frustración, del latín "frustra", es un adverbio que significa "en vano, inútilmente". La frustración puede ser efecto de un impedimento interno o externo que se interpone en nuestro camino hacia la consecución de un objetivo. Ello puede ser debido a la inutilidad de los esfuerzos o los méritos que podemos haber hecho por conseguir un objetivo que se nos resiste. La fábula de Esopo de la zorra que, por más saltos que dé, no alcanza las uvas, es un ejemplo paradigmático de este tipo de frustración.

En otras ocasiones la fuente de frustración es atribuible a la falta de consideración por parte de quien corresponda hacia los derechos que tenemos o creemos tener.

Percepción de injusticia

Lo importante no es determinar si la afrenta o el daño infligido, la ausencia de recompensa tras un esfuerzo o la falta de reconocimiento de un (pretendido) derecho, son o no justas, sino que lo que cuenta es la percepción subjetiva (egocentrada, desde mi punto de vista) de injusticia.

"Ella y solo ella es la responsable de mi dolor, jamás debió engendrarme, no sabe lo que significa ser madre, tener un hijo. Solo sabe utilizar, manipular, destruir. Su presencia engendra destrucción, desamor, odio. La odio. Sí, sí, sí, ella es culpable y debe sufrir las consecuencias. Yo no le pedí la vida. Si me la dio tiene la obligación de amarme y cuidarme, respetar mi parte afectiva y no lastimarme".

Los agravios o injusticias pueden provenir de otras personas, pero también pueden ser atribuibles a objetos inertes o a fenómenos de la naturaleza, a la sociedad, a la suerte o a la diosa fortuna, o a la absurdidad de la existencia.

\section{Clínica de la ira: la venganza}

La persona que se siente agraviada espera una reparación de su daño u honor. Si esto no sucede puede buscarla a través de la venganza. Este es el origen de los tribunales de justicia, cuyo fundamento es aplicar la venganza de una manera pro- 
porcionada y delegada (justicia vindicativa). En el pasado se admitían los duelos a muerte o el "delitto d'onore", ejecutados por la propia mano del ofendido, sobre la base de la ley del talión: "ojo por ojo y diente por diente".

Un episodio de la película “Relatos salvajes” dirigida por Szifrón (2014), nos presenta a Simón Fischer, un reconocido ingeniero, que intenta aparcar su coche donde mejor le conviene, mientras la grúa municipal se lo impide, llevándoselo al depósito una y otra vez... hasta la escena final, que constituye una explosión de violencia, mezcla de ira y venganza.

La venganza se sitúa en el colofón de la historia: una vez recuperado el coche, lo carga de explosivos y lo aparca descaradamente en zona prohibida. Espera que la grúa se lo lleve de nuevo al depósito municipal y lo hace explotar unas horas más tarde, mediante un dispositivo a distancia, causando diversos daños a las instalaciones además de un gran susto y alarma social. De este modo violento, pretende resarcirse de los “agravios sufridos”, a través de la agresión.

\section{Envidia}

Envidia, del latín “in-vidia” (in-videre) significa literalmente: mirar a alguien, fijar la vista en alguien, clavar la mirada. Por eso Dante en la Divina Comedia colocaba a los envidiosos en el infierno, con los párpados cosidos, para que no pudieran ver. Se envidian los bienes ajenos que el otro tiene y yo no, y por esta razón se fija la atención en él. Se le envidian:

- los bienes tangibles o materiales, heredados o adquiridos: la casa, el coche, los viajes, la pareja, los hijos, el trabajo, etc.

- los bienes intangibles o simbólicos, innatos o alcanzados que tienen un valor social: la fama, la suerte, el atractivo o la belleza, el éxito, etc.

La comparación es la operación mental previa que desencadena la envidia: «Si otro lo puede tener ¿por qué yo no?». Puedo estar muy contento y conforme con mi situación en la vida hasta que se me compara con la del vecino. Com-par-ar es buscar la paridad (igualdad) de uno con el otro. Alguien se siente inferior, porque no tiene lo que tiene otro o no en el mismo grado o no es de la misma cualidad. La comparación pone de manifiesto una in-iquidad, una falta de equidad (iniquidad: desigualdad percibida). Esta desigualdad puede ser objetiva o no, pero lo esencial es que sea percibida como tal por una de las partes.

\section{Clínica de la envidia: los celos}

Un caso particular de envida lo constituyen los celos, de zelum, un deseo muy intenso, que consume. Los celos son un calco de la envidia, pero aquí el bien ajeno deseado hace referencia a los afectos. Lo que se envidia es el amor, la preferencia o elección del otro, como prefería Dios los sacrificios de Abel a los de Caín, lo que llevó finalmente a Caín a matar a su hermano, Abel.

En los celos siempre aparece una tercera persona, formando un triángulo amoroso. Las personas implicadas pueden estar unidas entre sí por lazos preexistentes, 
como padres, hijos o hermanos. O pueden generarse tras la aparición de una tercera persona ajena a la relación, por ejemplo en el caso de una infidelidad o, incluso, entre los esposos ante el nacimiento de un hijo (Villegas y Mallor, 2017).

En la parábola del hijo pródigo (Lucas, 15:11-32), el hermano mayor experimenta celos porque a la vuelta de su hermano pequeño, que se ha gastado toda su herencia en malas compañías, es agasajado por el padre, mientras él considera que no ha recibido el mismo trato. Al quejarse ante él, porque nunca le ha hecho una fiesta como ésta, el padre le responde: Hijo, tú siempre estás conmigo, y todas mis cosas son tuyas. Pero era necesario hacer fiesta y regocijarnos, porque este tu hermano lo dábamos por muerto, y está vivo; se había perdido, y ha sido hallado.

\section{Codicia}

La codicia, de cupiditas en latín, está claramente relacionada con Cupido la versión romana del dios Eros, el deseo. Pero este deseo está orientado a los bienes materiales. En consecuencia, podemos definir el concepto de codicia como: "el acaparamiento excesivo de recursos que supone la obtención de un provecho o beneficio propio en perjuicio ajeno, mediante abuso o explotación".

Como resultado de la conciencia de estas necesidades y de la escasez de recursos para satisfacerlas se ha ido configurando progresivamente a través de los siglos un dinamismo psicológico orientado al acaparamiento y a la acumulación de los bienes de consumo, que llamamos codicia y avaricia, respectivamente. La codicia se considera un pecado capital, origen de los peores males del mundo: desigualdades económicas, explotación, abuso, crisis financieras, emigraciones, hambrunas, disputas territoriales, revoluciones, conflictos sociales y guerras. Los componentes de la codicia, tienen que ver con dos factores:

- la percepción de escasez de los recursos y

- el afán de acaparamiento de los mismos.

La avaricia se puede considerar una derivada de la codicia. El elemento que las diferencia tiene relación con el dispendio. La avaricia tiende a acumular bienes, recursos o dinero, evitando al máximo su dispendio. Se mueve por una motivación restrictiva: la escasez se percibe más en el gasto que la adquisición.

Si bien el acaparamiento y la acumulación de recursos en la historia de la humanidad ha sido una constante, como se puede comprobar a través de los restos arqueológicos de silos, bodegas o graneros en las más diversas civilizaciones y épocas históricas, estas prácticas tenían sus límites, debido en parte a la caducidad de los productos y en parte a la limitación del espacio.

La aparición relativamente reciente en la historia de la humanidad del dinero como sustituto intercambiable de cualquier producto ha favorecido, sin embargo, la potencial acumulación ilimitada en manos de unos pocos de todo tipo de productos que ya no requieren espacios físicos específicos, sino que pueden estar esparcidos por todo el mundo y que son renovables indefinidamente en la medida en que continúan produciéndose. Estos pocos, sean individuos o corporaciones, suelen moverse 
por una codicia insaciable, que no hace más que aumentar la distancia entre los ricos y los pobres. Especialmente afectadas se ven las clases medias, mermadas o destruidas, y la economía productiva, dejada al albur de la economía financiera.

Su referente mitológico bien podría ser el rey Midas. Hijo de un campesino que habiendo llegado al trono de Frigia por voluntad de los dioses, creció obsesionado por las riquezas. Por ello, cuando Dionisio (Baco) le ofreció satisfacer un deseo por haber ayudado a Sileno, un sátiro compañero suyo, Midas le pidió que todo lo que tocase se convirtiese en oro. Pronto pudo ver cumplido su deseo, que mantuvo tercamente a pesar de las advertencias en contra del dios del vino. Pero pronto también pidió renunciar a él, porque efectivamente todo lo que tocaba lo convertía en oro: las mujeres se convertían en estatuas de oro y la comida se transformaba en manjares de oro también. De este modo no podía ni siquiera comer y se veía condenado a morir de inanición y estéril sin dejar descendencia, aunque inmensamente rico.

\section{Clínica de la codicia: la "Affluenza"}

"Mata a cuatro personas, pero se salva de la cárcel, al aplicársele el diagnóstico de affluenza" (García Casado, 2014 febrero). Ethan Couch, de 17 años, el muchacho al cual se refiere el titular de la noticia, continúa la nota de prensa, "evita la cárcel, tras atropellar con resultado de muerte a cuatro personas, en estado de embriaguez y exceso de velocidad”. El accidente ocurrió mientras conducía una camioneta de su padre y después de haber robado dos cajas de cervezas en un supermercado. Iba acompañado por siete amigos, adolescentes como él, uno de los cuales resultó también herido de gravedad. En lugar de ir a la cárcel, ingresará en un centro de rehabilitación social, que costeará la familia. En el juicio sobre el accidente, ocurrido en el estado de Texas el 15 de junio de 2013, los abogados alegaron "affluenza", como eximente. La enfermedad, según el abogado texano Scott Brown, "impide a los hijos de los ricos tener una noción clara de la gravedad de sus actos”.

El término fue creado en 1996 por la psicóloga Jessie O’Neill, nieta de un presidente de la General Motors, que en The Golden Ghetto: The Psychology of Affluence se refería a que los hijos de familias opulentas no miden en ocasiones las consecuencias de sus actos. El concepto se popularizó en 1997 gracias a la exitosa película homónima de John de Graaf, una mirada mordaz a las consecuencias del consumismo y el materialismo en EE. UU. También en la película "The Joneses", escrita y dirigida en 2009 por Derrick Borte, se pone de manifiesto el grado de insatisfacción, resultado de la comparación con el nivel y los bienes materiales de los vecinos, que induce a aumentar estúpidamente el consumo competitivo entre los componentes de una misma clase social.

Esta pretendida enfermedad que no consta en ningún manual de diagnóstico psicológico ni psiquiátrico, se describe en Wikipedia como una "enfermedad dolorosa y contagiosa de transmisión social, consistente en sobrecarga, endeudamiento, ansiedad y despilfarro como consecuencia del obstinado empeño por poseer más”, 
o de una manera más simplificada, como "adicción irrefrenable al crecimiento económico, fruto del sueño americano". En un informe psicológico el abogado alegaba:

"Este chico lo ha tenido todo. Sus padres son enormemente ricos; siempre ha hecho lo que ha querido, nunca le han puesto límites y sólo ha aprendido a considerar o a valorar lo material y el consumismo desenfrenado, siendo incapaz de establecer un criterio de conexión entre sus actos y las consecuencias de su comportamiento, debido a que sus padres le enseñaron que con el dinero todo se puede".

\section{Lujuria}

La palabra lujuria, derivada del latín luxus (lujo) hace referencia a exceso. Como tal no se limita al contexto de la sexualidad, sino a la experiencia incontenible del deseo. Con el tiempo este deseo se ha ido circunscribiendo al deseo sexual, para el que se ha reservado el concepto de lujuria y, el de lujo, a cualquier tipo de manifestación ostentosa. La lujuria no es un pecado contra la naturaleza ni contra Dios, sino que puede ser el origen de otros pecados y, por tanto, pecado capital. Ya Epicuro (2007) en sus "Sentencias Vaticanas" (Fragmentos, 51) escribía:

"Acabo de enterarme de que tus excitaciones carnales se hallan demasiado propensas a las relaciones sexuales. Tú, siempre y cuando, no quebrantes las leyes, ni trastornes la solidez de las buenas costumbres, ni molestes al prójimo, ni destroces tu cuerpo, ni malgastes tus fuerzas, haz uso como gustes de tus preferencias. Pero la verdad es que es imposible no ser cogido al menos por uno de esos inconvenientes, el que sea. Pues las cosas de Venus jamás favorecen y por contentos nos podemos dar si no perjudican”.

La dimensión moral le viene a la sexualidad de su dimensión relacional, que es donde se juegan los temas de fidelidad o respeto y sus contrarios; es la que nos abre a entender la lujuria como pecado capital. Introduce en la lujuria la dimensión erótica, el deseo del otro, más allá de la dinámica fisiológica de la pulsión. De la dimensión interpersonal se deduce que la lujuria pecaminosa no se define por el exceso o la intensidad del deseo, sino por la perversión de su objetivo amoroso: la fusión, la posesión, la traición, el dominio, el abuso, la violación, la humillación, la vejación, la destrucción, etc., la cosificación, en definitiva, del sujeto amoroso, convertido en obscuro objeto de deseo.

Muchas de estas conductas se ponen de manifiesto en comportamientos "cotidianos” en los ámbitos laborales, profesionales, académicos, artísticos, políticos, etc. en forma de chantaje sexual como medio de promoción, elección, preferencia, posibilidad de acceder a un contrato, etc., como ponen de manifiesto muchos testimonios recogidos bajo el hashtag “\#MeToo". Otras veces en forma de acoso físico o verbal, tocamientos, manoseos, comentarios soeces o provocativos, sin otro contexto relacional que el de la impulsividad del acosador en espacios públicos o privados, que presuponen una posición de poder abusivo sobre la víctima, aunque no comporten una violencia explícita como en las violaciones. 


\section{Clínica de la lujuria: la desigualdad}

La historia de la sexualidad humana es, en parte, una historia de desigualdad, abuso, dominio y sumisión, basada en las propias diferencias biológicas, en detrimento casi siempre de las mujeres, los niños o las clases explotadas. En la moral sexual romana la oposición era someter/ser sometido, donde someter (penetrar) era loable para los varones libres, ser sometido (ser penetrado) era lo natural para mujeres o esclavos.

Este esquema ha predominado en las sociedades patriarcales de todos los tiempos y culturas. Algunas religiones han intentado paliar este desequilibrio, predicando la igualdad de hombres y mujeres ante Dios. Fuera del ámbito religioso la literatura romántica, a veces en base a historias reales, como las de Abelardo y Eloísa, o fantaseadas, como las de Romeo y Julieta, ha querido subrayar también esta igualdad. Movimientos sociales, mucho más recientes de carácter laico como el feminismo, la reivindican también de forma contundente.

Para entenderse, hombres y mujeres, en la vida sexual, tienen que partir de dos principios: que hombres y mujeres son ontológicamente iguales, aunque no lo sean desde el punto de vista sexual. Las diferencias anatómicas no justifican ningún tipo de discriminación desde el punto de vista evolutivo, antropológico, psicológico, moral, social, laboral y legal, donde todos somos iguales.

El problema se plantea en las relaciones interpersonales mediadas por el sexo, es decir, erotizadas, para las que, como dice el filósofo francés Compte-Sponville (2001), deberemos ser capaces de crear espacios de libertad, reciprocidad e igualdad, independientemente de la orientación hétero- u homosexual.

\section{Cuando «sí» quiere decir «no»}

Si partimos del principio de preservar la igualdad en las relaciones sexuales, ésta se puede proteger solo en base al mutuo consentimiento. Los movimientos sociales feministas han insistido muy acertadamente en que No es NO y solo Sí es Sí. Con todo conviene advertir que no es lo mismo asentimiento que consentimiento. Y que éste último solo se puede calificar como tal, si se basa en una decisión plenamente libre.

El supuesto consentimiento, en efecto, está con frecuencia condicionado a otros fines, como contentar a la pareja o no querer decepcionarla, pero no por eso es libre, como puede verse en el caso de Susana, quien se siente mal porque cree que no es capaz de satisfacer sexualmente a su marido que siempre se muestra de mal humor. Está convencida de que si él estuviera satisfecho sexualmente se sentiría mucho más contento y todo iría mejor. A fin de reparar la insuficiencia de sus prestaciones accede a acudir a locales de intercambio de parejas y hasta alquilar los servicios de alguna prostituta en casa. Lo cuenta así:

Susana (S): Hemos ido durante cierto tiempo a un local de estos de intercambio de parejas... La primera vez fue horrible: al entrar hay una sala oscura donde la gente baila y se toquetea. Es muy incómodo porque no 
sabes quién te está tocando. Él, en cambio, se lo pasaba muy bien... Acudimos en otras muchas ocasiones y yo me sentía fatal, podríamos decir... violada, muy desagradable, un asco, porque si ya me gusta poco el sexo, ¡imagínate con desconocidos!

Terapeuta (T): ¿Pero continuaste yendo?

S.: Sí, pero yo no le dije a él cómo me sentía; en realidad hacía ver que me lo pasaba bien para no aguarle la fiesta.

T.: ¿Pero él sabe que no te gusta?

S.: No... no se lo he dicho nunca... No, es que me sentí fatal; primero sorprendida: "¿qué hago yo aquí?». Y sabiendo que a mí el sexo ya no me gusta mucho, pues imagínate... y ver el panorama y la cara que ponía él, de mucha emoción, como alucinando.

T.: Y por la cara de alucinado que ponía, ¿fuiste incapaz de decir nada?

S.: Sí, por aquella cara y porque se lo pasaba tan bien..., decidí callar.

Moraleja: si quieres estar seguro del consentimiento en una relación sexual, no te conformes con obtener el consentimiento voluntario, asegúrate que también es libre.

\section{Gula}

La palabra gula proviene de la misma palabra en latín gula, relacionada con gola (boca) o glotis (en griego), de donde deglución. Está pues asociada a la actividad bucal de la deglución (comer o beber). La comida y la bebida cumplen la función primaria de asegurar el sustento. Pero a la vez son, o pueden ser, una fuente de placeres, de escrúpulos morales o preocupaciones dietéticas según la perspectiva con que se aborden. De modo que la gula implica el consumo de alimentos. Siendo ésta una actividad esencial para la supervivencia del individuo y de la especie no acaba de entenderse en qué sentido se puede asociar el comer o el beber con un vicio o pecado capital. La gula o su contraria la abstinencia deben tener alguna característica que la haga especifica del ser humano. Este valor simbólico probablemente cubra diversas funciones conjunta o separadamente, entre las cuales podemos señalar la compulsiva, la ansiolítica y la ostentosa.

De una manera muy esquemática quedan así planteados los temas relativos al significado de la comida para el animal humano. En efecto, no hay tal vez hoy en día un tema más polémico que el de la comida. Siendo el ser humano el animal omnívoro más completo, es el único que se plantea la licitud o conveniencia de multitud de alimentos, capaz de contar el número de calorías o la cantidad de grasas saturadas, monoinsaturadas y poliinsaturadas para cada ingesta. El único que se plantea beber la leche con lactosa o sin ella o sazonar los alimentos con azúcar, sal, pimienta o sin ellos. La especie que es capaz de establecer distinciones entre animales sagrados e impuros, de discutir el modo ritual cómo debe ser cortado el cordero; y así hasta el infinito. Algunas de estas cuestiones, elevadas a categoría de tabú religioso, son causa de disquisiciones científicas y hasta teológicas. La única 
especie que desarrolla teorías, ideologías, dietas, prácticas hedonistas o ascéticas alrededor de la comida, la única que por estas mismas razones está expuesta a todo tipo de trastornos alimentarios, es la humana. Estas cuestiones dietéticas, independientemente de su origen ideológico, tienen notable incidencia sobre las conductas alimentarias problemáticas de las que se ocupa la psicología clínica, tales como la anorexia, la ortorexia, la vigorexia, la bulimia o los atracones.

\section{Clínica de la gula: la comida como ansiolítico}

Si el hambre es percibida con una sensación de vacío en el estómago, nada tiene de extraño que la ansiedad o la angustia se asocien con el hambre, puesto que la experiencia de vacío es uno de los indicadores más frecuentes de angustia. Esta es una de las sensaciones más frecuentemente referidas por las personas que padecen bulimia o que practican el atracón. El diálogo con Juana que reproducimos a continuación lo expresa claramente.

Juana, paciente de 31 años, separada desde hace algunos meses, vive con sus padres, ha iniciado una nueva relación con Marcos, aunque no convive todavía con él al no haber formalizado la ruptura con la pareja anterior, toxicómano, que la había recluido y maltratado física y psicológicamente.

Inicia la sesión relatando que ha acudido a una entrevista en un hospital público para ser aceptada en un programa de tratamiento para trastornos alimentarios. Expresa una intensa decepción por el trato burocrático a que fue sometida en esta entrevista, que duró apenas dos minutos, y el impacto que le causaron las chicas anoréxicas con las que tuvo ocasión de cruzarse por los pasillos del departamento. Este caso resulta particularmente relevante por el hecho de no presentar una distorsión de la imagen ni una preocupación por el peso, por lo que el ciclo atracón-vómito se manifiesta nítidamente en su naturaleza.

Juana (J):: Es que solo llegar allí y ver lo que hay, ya empiezo a pensar, ¿por qué todas las chavalas están tan delgadas?, digo, si yo estoy de gloria. Yo veo las otras, porque yo he perdido más de treinta quilos, pero claro yo tenía chicha. Y la otra se hace lo mismo que yo, y no tiene chicha. Pero es que eran delgadas a más no poder, es que éstas no comen ni nada. Yo me veo gorda al lado de ellas. Son sacos de huesos andantes. Yo sé que estoy compensada por mi peso. Lo que pasa es que mi constitución es de ser más ancha... Pero anoche, después de ver todo aquello en el hospital, me comí un bocadillo enorme. He pasado la noche de perros, pero no vomité el bocadillo. Recuerdo lo que había allí y me pongo enferma, se me quitan las ganas de vomitar.

Terapeuta (T).: Porque ¿lo que comes, lo vomitas?

J.: Sí, porque se me meten los nervios aquí en el estómago, como si fuera un bajón. Pero me puedo comer todo lo inimaginable, todo lo que pillo, y luego claro, me sienta mal. Pero anoche me quedé pensando: ¿cómo voy a vomitar? Me tengo que curar, me tengo que poner bien... 
T.: Por lo que dices parece que todo esto está relacionado con la sensación de ansiedad.

J.: Sí, así es. Siempre me ha pasado, las temporadas que he estado muy nerviosa. Esto no es de ahora. De cuando me pasó lo de mi marido hace ya años. Entonces estaba muy gorda, pesaba ochenta y seis quilos. Paseábamos por la calle. Me daba vergüenza, con veintitrés años. Y claro, tanto machacarme con "estás gorda", me metía de todo para adelgazar, pero no adelgazaba, engordaba más. Y venga hacer dieta y venga pastillas. T.: ¿Cuánto hace que empezaste a utilizar este sistema de atracarte y vomitar para calmar los nervios?

J.: De esto hace ocho o nueve años... Mi marido hacía su vida, pasando de mí, total. Él se iba a trabajar y venía a los tres días. Y si venía con algún problema, me dejaba en casa allí, como si yo no existiera. Pues yo que sé, a mí me daba por comer. Si estaba yo todo el día en casa, ¿qué hacía?, pues, comer.

T.: O sea, que estabas todo el día en casa, y estabas pensando en qué estaba haciendo él.

J.: Sí, de los mismos nervios; pues el aburrimiento, me daba por comer. Sí, me podía comer dos pasteles. Tengo el recuerdo de estar sentada en el sofá con mi pastel. Es que no me podía ni mover... A ver, era cuando, a lo mejor me tiraba semanas sin vomitar. Pero luego, según el estado de nervios que tuviera, según lo aburrida que estuviera, pues eso me llevaba a comer y a vomitar.

T.: Y luego, vomitar ¿para qué te servía?

J.: Pues para quedarme tranquila, porque me hinchaba de tanto comer. Claro, luego no podía ni respirar. De la ansiedad que tenía dentro, de haber comido tanto. Si me podía comer lo que se come una familia.

T.: Entonces resulta que estabas aburrida o estabas ansiosa y comías, y luego vomitabas porque te ahogabas de tanta comida. Cuando vomitabas, ¿en qué pensabas?

J.: Pensaba en quitarme esa pesadez que tenía en el cuerpo. Igual que ahora, como y me siento pesada, una mala leche que me entra. Muchas veces prefiero no comer, para no sentir esa mala leche.

Finalmente, podemos entender la gula, también, como despilfarro o consumo voraz de los recursos necesarios para la supervivencia de los seres humanos, en conexión con la falta de conciencia de escasez, emparentada con la codicia, por lo que se convierte en un pecado ecológico, que favorece la explotación y destrucción del habitat planetario.

\section{Pereza}

La pereza (del latín: pigritia) puede definirse como: "negligencia, astenia, tedio o descuido en la realización de actividades”. 
Para que la inacción pueda ser entendida como indicador de pereza se supone que la actividad debe estar negativamente motivada, como falta de ganas de emplear energía para alcanzar cualquier objetivo. Y que esta abulia se pueda considerar generalizada como una actitud ante la vida, por la que se valora como más gratificante el ahorro de energía que el dispendio de ésta, la evitación del esfuerzo, que sus posibles logros.

Lainacción forma parte del ciclo natural actividad-reposo (esfuerzo-descanso). La acción está motivada por necesidades inmediatas de subsistencia, como los animales que están en reposo cuando no pacen o cazan. En el Paleolítico, por ejemplo, no habría lugar a hablar de pereza. Se entraba en acción cuando era necesario. En el Neolítico, en cambio, se inicia la regulación económica. El ciclo actividad-reposo se considera dentro de los parámetros ocio-negocio, motivado por fines diferidos: consecución de bienes a largo plazo.

Por ocio se entiende una actividad no productiva creativa, recreativa o de entretenimiento, o una inactividad contemplativa de regulación espontánea respecto al tiempo libre: pasar el tiempo, contemplación, aburrimiento, juego, diversión (la cigarra de la fábula de Esopo, que pasaba el verano tocando la guitarra).

Por negocio se entiende una actividad productiva destinada a la obtención de un beneficio; obedece a una regulación planificada, la consecución del objetivo se difiere en el tiempo, cautivo de esta intencionalidad (la hormiga, que se pasaba el verano almacenando grano para el invierno).

El ocio en sí, entendido como tiempo liberado, no es ni bueno ni malo. Depende del uso que se haga, con qué fines y con qué resultados. Filósofos y monjes, tanto orientales como occidentales, estructuraban su vida de modo que pudieran liberar gran parte de su tiempo para dedicarlo a la contemplación, reflexión, meditación o, en general, a la vida espiritual ("ora et labora").

Este tiempo liberado de obligaciones puede provenir de dos condiciones previas:

No tener que hacer nada: no estar obligado, ni necesitado; estar libre, tiempo libre. No tener nada que hacer: estar desocupado (falta de ocupación), estado de inactividad: «dolce far niente». La pereza se entiende en referencia al tiempo cautivo, no al tiempo libre.

\section{Clínica de la pereza: la procrastinación}

En este contexto ocio-negocio, la pro-crastinación significa literalmente «dejar para mañana lo que puedes hacer hoy». Existen diversos motivos por los que una persona se pueda sentir tentada de aplazar la ejecución de los pasos necesarios para alcanzar la consecución de un objetivo:

- La connotación o valencia negativa de este objetivo. Si el objetivo carece de interés o su consecución implica un esfuerzo aversivo, se tenderá a aplazar su realización.

- La falta de recursos para llevar a cabo las tareas exigidas. Si la persona no posee los medios necesarios para alcanzar un fin, evitará aproximarse a él. 
- La expectativa de reconocimiento meritocrático: perfeccionismo. Si se pone en juego el propio valor a través de la consecución de un objetivo, nunca se estará suficientemente preparado para alcanzarlo.

\section{Una procrastinación indefinida}

Cristina, de 34 años se presenta a terapia porque no consigue remontar en su vida profesional. Tiene muchos proyectos y ganas de hacer cosas, trabajar, continuar formándose, estabilizar su relación de pareja, pero se siente desbordada por todo y ya lleva un tiempo que ha hecho un crack, con ataques de pánico y ansiedad generalizada, hasta el punto de tener que dejarlo todo y coger la baja laboral. Había llegado a quedarse bloqueada no solo mentalmente, sino hasta físicamente.

En su caso podemos encontrar todos los factores que pueden llegar a intervenir en la procrastinación: motivación negativa, falta de recursos y perfeccionismo meritocrático: la imagen que quiere dar de sí como "mujer orquesta”, que le lleva hasta el bloqueo, se pone de manifiesto ya en sus primeras palabras:

"Yo siempre he sido la que no tiene ningún problema, que escucho los problemas de todos los demás, la que es fuerte y puede con todo. $Y$ de repente te dices "no puedo más". Y entonces, yo lo que tengo es un cansancio o sea me he llegado a quedar bloqueada de bueno de tenerme que levantar alguien, porque mi cuerpo no responde. Pero yo en el fondo sé que soy muy fuerte, muy impulsiva y muy impaciente; o sea, cuando me veo bien ya arrancaría a correr y entonces mi cuerpo me dice que no, que no... Aunque yo siempre, he corrido siempre, lo he podido hacer todo ¿no?... Nunca estoy contenta, nunca tengo bastante; llevo mi trabajo, mi casa, mis estudios (narcisismo meritocrático)... Entonces dejé de trabajar, bueno, me echaron porque cogí la baja... Me da pánico adquirir esa responsabilidad de ir a un sitio unas horas cada día ¿no? Pues yo empecé a parar primero de todo eso cogiendo la baja y desentendiéndome de esa relación laboral; a parte yo trabajaba en algo que no me interesaba (motivación negativa); pero yo soy perfeccionista... yo trabajaba con un amigo que estábamos remontando una empresa y llegó un momento que no sabía ya ni dónde tenía los papeles (falta de recursos). Pues yo, por ejemplo, lo del perfeccionismo es algo que ahora quiero trabajarme, tomármelo con más calma...”.

Otras variantes clínicas de la pereza pueden considerase: la acidia, la desidia y la negligencia.

La palabra acidia, (del griego akedia, "falta de cuidado"), significa descuido de sí. «El hombre virtuoso no puede ser una carga para los demás, por eso debe cuidarse de sí mismo. El cuidado de sí es éticamente primordial, en la medida en que la relación consigo mismo es ontológicamente la primera. El cuidado de sí resultará también beneficioso para los demás» Foucault (2002).

Desidia del verbo latino "de-sedere", significa "quedarse sentado", sin hacer nada. Es, por definición, inacción, generalmente como resultado de rehuir el esfuerzo (indolencia) y/o de mantener una actitud ambigua respecto al valor de la 
vida o de la existencia humana, fruto de la mezcla de superioridad y de desprecio con que nuestra mirada narcisista nos sitúa frente al mundo.

\section{Negligencia $\leftrightarrow$ diligencia}

Ambas palabras comparten una raíz etimológica común, una en positivo (diligencia), amor o interés por algo, la otra en negativo (neg-ligencia) negación de este amor; emparentada con la pereza en cuanto es hija del desinterés que convierte en negativa la motivación. Gran parte del sufrimiento humano proviene de la dimisión o indiferencia ética en aras del hedonismo egoísta, de la falta de compromiso responsable con la existencia.

El pecado capital de la pereza no está relacionado con el uso del tiempo cronológico, sino con el del tiempo ético. Este es el pecado capital de la pereza: la negligencia.

\section{Consideraciones Finales}

Replantear la idea de "pecados capitales" desde una perspectiva laica y actualizada nos lleva a redefinir los conceptos. Ya no se trata de pecados contra la divinidad, sino contra la humanidad. El pecado es concebido, en primer lugar, no como un error, sino como un daño producido a nuestros semejantes a causa de nuestro egoísmo moral. Desde esta nueva perspectiva hemos redefinido:

- La soberbia, como una posición de superioridad y dominio sobre los otros, derivada de un narcisismo exacerbado y egocéntrico, que impide ver a los demás como sujetos.

- La ira, como un derecho autoatribuido de restaurar la injusticia percibida, mediante la agresión o la venganza.

- La envidia, como fruto de la comparación y la rivalidad que llevan a percibir el mal ajeno, como bien propio.

- La codicia, como acaparamiento de los recursos económicos en detrimento de un reparto justo entre los humanos para subvenir a sus necesidades.

- La lujuria, como legitimación de la desigualdad en función de los derechos del impulso posesivo y del deseo fusional de una sexualidad dominadora.

- La gula, como despilfarro de los bienes de consumo disponibles, en detrimento de los recursos naturales de la tierra.

- La pereza, como desidia moral frente a nuestras obligaciones éticas hacia el mundo y hacia los demás, por negligencia o falta de compromiso.

La mirada psicológica que hemos dirigido sobre los siete pecados capitales, nos permite considerarlos en una óptica más moderna, a la vez que atemporal: la de una perspectiva intersubjetiva y social, desligada de sus orígenes filosóficos o religiosos. Retomar la idea de culpa y pecado, como reconocimiento del daño causado a los demás, a partir de motivaciones egocéntricas dominantes, nos lleva a reintroducir en psicología la dimensión moral y la responsabilidad, de la que el ser humano no puede, ni debe sustraerse. 


\section{Referencias Bibliográficas}

Almodóvar, A., Almodóvar, P., García, E. Mosteirín, M., Rozín, G., Sigman, H. (Productores) y Szifrón, D. (Director) (2014). Relatos salvajes (Película). Argentina: El Deseo y K\&S.

Compte-Sponville, A. (2001). A Short Treatise on Great Virtues. Londres, Reino Unido: William.

Epicuro (2007). Obras. Madrid, España: Biblioteca Gredos.

Escur, N. (2011, abril 11). Entrevista André Comte-Sponville. La Vanguardia, Recuperado de: https://www.lavanguardia.com/cultura/20110411/54139590727/andre-comte-sponville-nos-ha-tocado-vivir-en-la-sociedaddesorientada.html

Evagrio Póntico (2013). Obras espirituales, Madrid, España: Editorial Ciudad Nueva.

Foucault, M. (2002). La ética del cuidado de sí como práctica de la libertad. En C. Gómez (Ed.), Doce textos fundamentales de la ética del siglo xx (pp. 256-264), Madrid, España: Alianza.

García Casado, C. (2014, febrero 06). Mata a cuatro personas, pero se salva de la cárcel al diagnosticarle "affluenza”. La Vanguardia. Recuperado de: https:/www.lavanguardia.com/sucesos/20140206/54399962867/ el-polemico-caso-del-joven-con-afluenza-se-salda-con-terapia-y-no-carcel.html

Mankoff, D. (Productor) y Borte, D. (Director) (2009). The Joneses (Película). Los Ángeles, CA: RoadsideAttractions.

María Moliner (2007). Soberbia. Diccionario de uso del español ( $3^{\mathrm{a}}$ ed.). Barcelona, España: Gredos

O’Neill, J. H. (1996). The Golden Ghetto: The Psychology of Affluence. Hazelden, CA: Publishing \& Educational Services.

Real Academia Española. (2019). Soberbia. Diccionario de la lengua Española (23.3 ${ }^{\mathrm{a}}$ ed.). Recuperado de: https://dle.rae.es/soberbia

Villegas, M. (2018). Psicología de los siete pecados capitales. Barcelona, España: Herder.

Villegas, M. y Mallor, P. (2012). El narcisismo y sus modalidades. Revista de Psicoterapia, 23(89), 59-108. Recuperado de: https://ienda.revistadepsicoterapia.com/catalog/product/view/id/1004/s/el-narcisismo-y-susmodalidades/category/3/

Villegas, M. y Mallor, P. (2015). Estima ontológica, estima narcisista. Revista de Psicoterapia, 26(100), 3-44. Recuperado: http://ojs.revistadepsicoterapia.com/index.php/rdp/article/view/74

Villegas, M. y Mallor, P. (2017). Parejas a la carta. Las relaciones amorosas en los tiempos posmodernos. Barcelona, España: Herder.

Villegas, M. y Mallor, P. (2018). “El Perfume” del Narciso. La terapia como validación del ser. En I. Caro (Ed.), Cine, metáforas y psicoterapia (pp. 39-49). Madrid, España: Pirámide. 